\title{
Comparison of Offshore Wave Measurements
}

\author{
MICHAEL W. SZABADOS AND DINORAH C. ESTEVA
}

(Invited Paper)

\begin{abstract}
Preliminary results of a comparison between several wave measurement systems used during the Atlantic Remote Sensing Land Ocean Experiment (ARSLOE) are presented. Measurements in the offshore region $12-40 \mathrm{~km}$ offshore, taken during a storm that occurred October 23-26, 1980, are compared. Disagreement between significant waveheights resulting from the different measurement systems in some cases are larger than can be explained by random variability.
\end{abstract}

\section{INTRODUCTION}

$\mathbf{O}_{1}$ NE OF THE PURPOSES of the Atlantic Remote Sensing Land Ocean Experiment (ARSLOE) was to test and compare available wave measurement systems. The configuration of wave measurement systems covered a $30-\times 40-\mathrm{km}$ region off the coast of Duck, NC. The comparison presented here concentrates on measurements in the region $12-40 \mathrm{~km}$ offshore taken during a 4-day period from October 23-26, 1980 , when a storm passed through the site area. The storm consisted of a complex frontal system which generated waves with a significant height of approximately $5 \mathrm{~m} \mathrm{[1]}$

Table I summarizes those measurement systems to be discussed. The locations of these systems are displayed in Fig. 1. The Cloverleaf Directional Buoy measured waves in various locations ranging from $12-40 \mathrm{~km}$ offshore while tethered to the research vessel Cape Henlopen. The locations for the Airborne Radar systems shown in Fig. 1 represent the approximate location of the center of the flight pattern. Most buoy measurements are either at 12 or $36 \mathrm{~km}$ offshore.

There are some difficulties and limitations when comparing different instrumentation in situ. It would be ideal to compare measurement systems so that any discrepancy found could be attributed only to the differences in the systems themselves and not to sampling variability. Since this is not possible even for two closely spaced in situ systems, consideration must be given to the effect of sampling variability. Additional variability should be expected between results from in situ instruments and from remote sensing instruments which measure over a finite area.

ARSLOE ALPHA, a study prior to ARSLOE, was conducted to provide a measurement of the sampling variability. Three Waveriders were deployed in a line parallel to shore at the $12-\mathrm{km}$ site with the two outermost buoys positioned $1 \mathrm{~km}$ apart. All three instruments were standard Datawell Waverider buoys, calibrated as described by Ribe [2]. The moorings used were basically of Datawell design, modified by the Engineering Development Office of NOAA and de-

Manuscript teceived February 15, 1983 ; revised June 20, 1983.

The authors are with the National Ocean Service, Rockville, MD 20852.

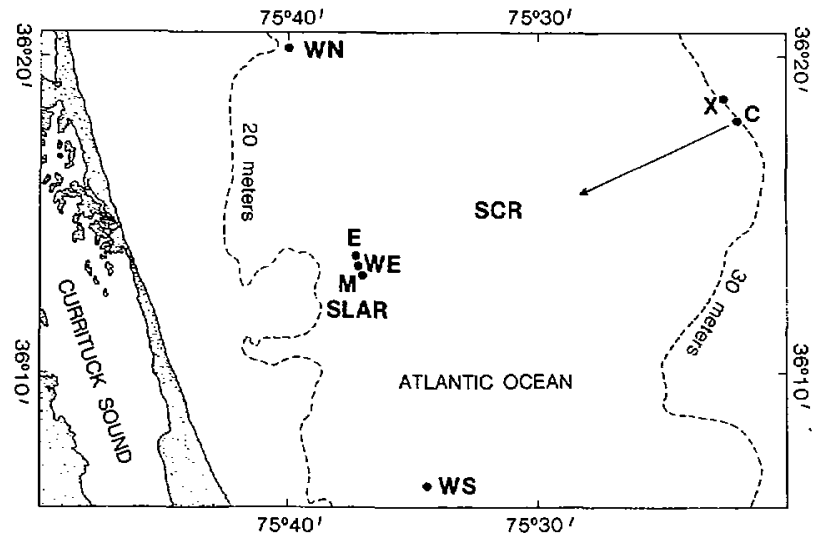

Fig. 1. Station locations: E-ENDECO Wavetrack Buoy, WE-Waverider East Buoy, WN-Waverider North Buoy, WS-Waverider South Buoy, M-Canadian "MET" Buoy, X-XERB Buoy, C-Cloverleaf Buoy, SCR-Surface Contouring Radar, SLAR-Side Looking Airborne Radar; --indicates a buoy system.

scribed in Kahn [3]. The buoy at the central location malfunctioned shortly after deployment, thus none of its measurements are considered in this work. This buoy was later replaced with another Datawell system which operated during ARSLOE. Fifty seven pairs of concurrent measurements were collected from the outermost buoys. Data were processed and analyzed with the same software package.

Estimates of the same variable obtained from adequately spaced, different, though equivalent systems are expected to belong to the same population. Thus the combined set of estimates from the two systems should be randomly distributed, with approximately half the estimates from one system being higher than the estimates from the other. To test whether this randomness was exhibited by estimates of significant waveheight $\left(H_{s}\right)$ values from the two outermost buoys, the ratios of pairs of their simultaneous $H_{s}$ estimates were examined. As shown in Fig. 2(a) and Table II, the ratio values were equally distributed about one. Thus, it is accepted that although $1 \mathrm{~km}$ apart, both buoy systems are sampling the same population.

It was determined that the two systems yield the same results for $H_{s}$ by two methods: the comparison of confidence intervals and the $F$ Test. First, the significant waveheights were compared at the 90-percent confidence interval for each buoy. In this case, 81 percent of concurrent pairs of samples from the same population should be expected to fall within each other's confidence interval. For the data set, 80.7 percent (46 pairs) passed this test. Secondly, the assumption was tested under the hypothesis that corresponding pairs of $H_{s}$ measurements are equal using the $F$ distribution. The hypothe- 
TABLE I

WAVE MEASUREMENTS SYSTEMS COMPARED

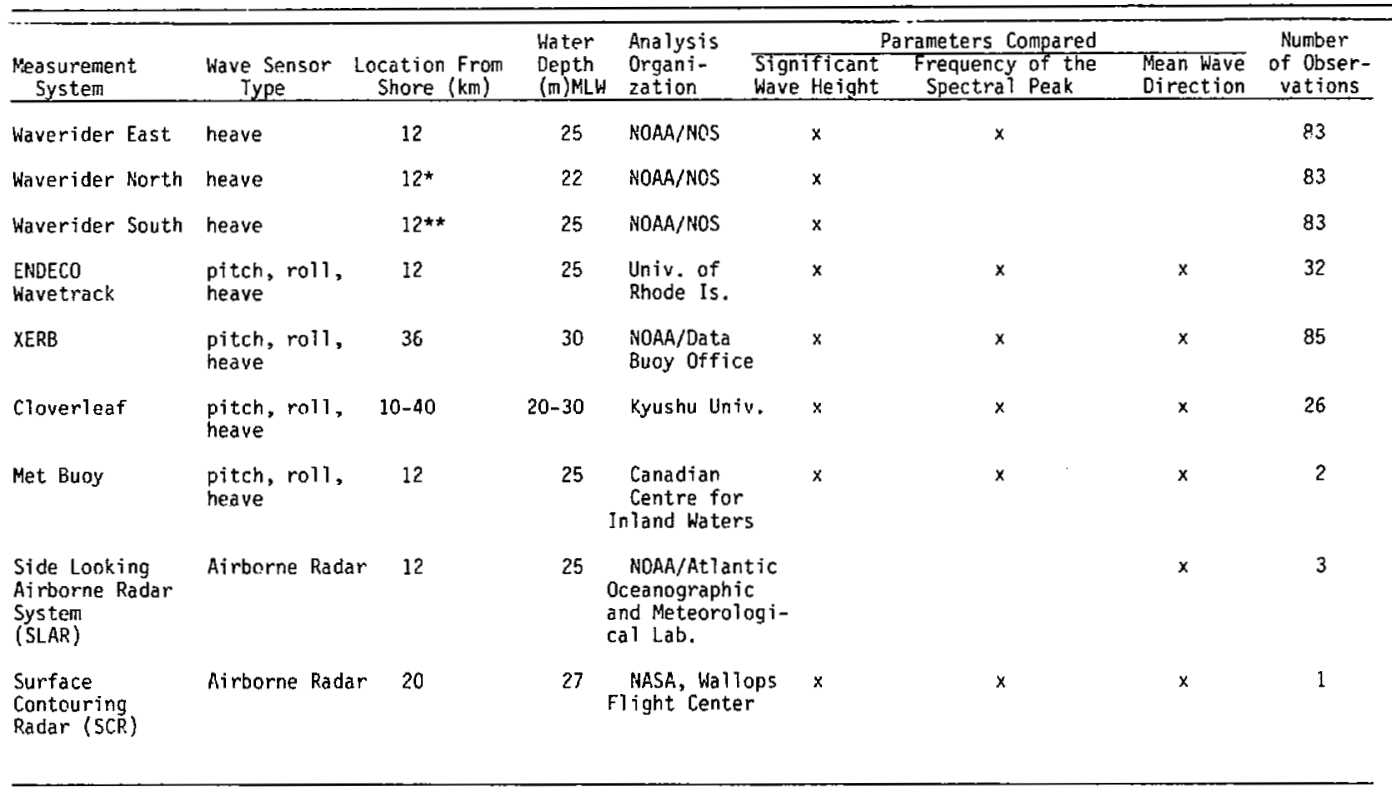

* Located $15 \mathrm{~km}$ North of Waverider East

** Located $15 \mathrm{~km}$ South of Waverider East

sis could be accepted at the 90-percent confidence level (Table II); that is, about 10 percent of the $H_{s}$ ratio values failed the $\mathrm{F}$ test at the 90-percent level. It is concluded from these tests, which confirm each other, that the two buoys were measuring the same results for $H_{s}$ and disagreements in resulting measurements from the two Waveriders may be attributed only to sampling variability.

\section{METHOD OF ANALYSIS}

Since participants were responsible for the processing and analyses of their data, the methods described in this section pertain only to Waveriders which were analyzed by the authors. For details on the analysis of other measurement systems, the respective participants should be contacted. Some of the participants are presenting their findings in this issue. The names of those contributing their data for this comparison can be found in the acknowledgment.

The Waverider signal was sampled at a $4-\mathrm{Hz}$ rate. The time series was separated into sections of 4096 data points representing a 1024-s duration, and a fast Fourier transform (FFT) algorithm was used to compute spectra from each section. To reduce side lobe leakage in the spectral estimates the Tukey or cosine bell window

$$
w(N \Delta t)=1 / 2[1-\cos (2 \pi n / N)]
$$

was applied before the Cooley-Tukey FFT method for computing the complex Fourier series

$$
A_{j}=t \sum_{n=0}^{N-1} A_{k} \exp (2 \pi i j k / N)
$$

was used. The spectral estimates were then corrected for variance loss due to the window by forcing the variance under the estimated spectrum to equal the variance computed from the time series before application of the window. Calibration corrections which are frequency dependent, were applied after correcting for the window effect. The applied corrections did not include temperature effects on Waverider sensitivity. This omission introduced an amplitude error not greater than 1 percent for the temperatures observed during the storm [2] .

The spectral estimates were band-averaged over 11 adjacent frequencies resulting in spectral estimates with frequency resolution of $0.011 \mathrm{~Hz}$ and 22 degrees of freedom.

Assuming a narrow-band spectrum, the significant waveheight was calculated from

$$
H_{s}=4 \sqrt{m_{0}}
$$

where $m_{0}=$ area under the wave spectrum [4] .

The 90-percent confidence limits for the true significant waveheight $H_{s}^{\prime}$ were found by

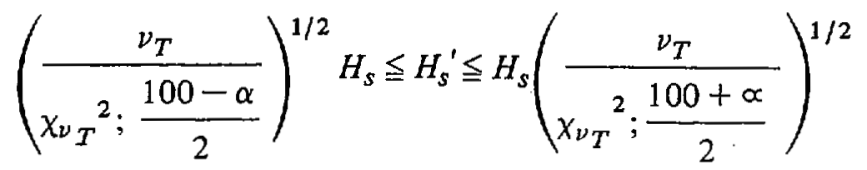

where $H_{S}$ is the estimated significant waveheight, $\chi^{2}$ values are obtained from a chi-square distribution, and $\nu_{T}$ are the total degrees of freedom from

$$
v_{T}=\frac{2\left(\sum_{n} E_{n}\right)^{2}}{\sum_{n} E_{n}{ }^{2}}
$$

where $E_{n}$ is wave variance at the $n$th Fourier frequency and the summations are overall Fourier frequencies. 


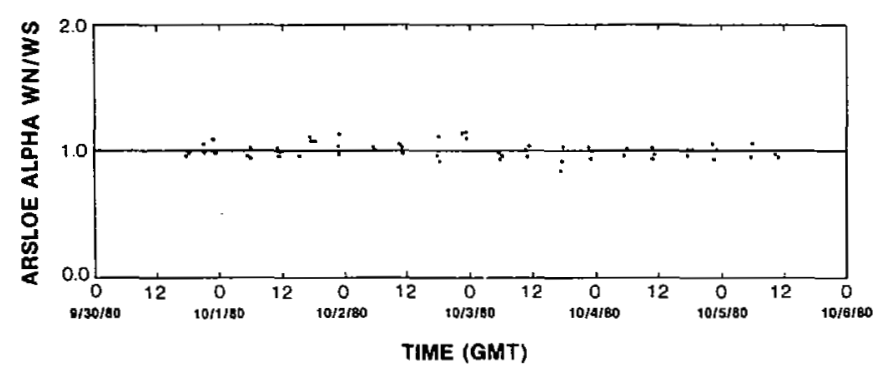

(a)

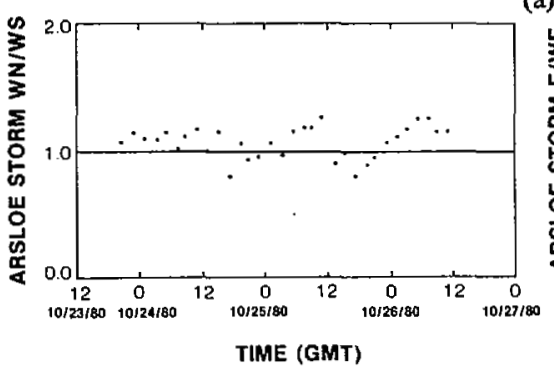

(b)

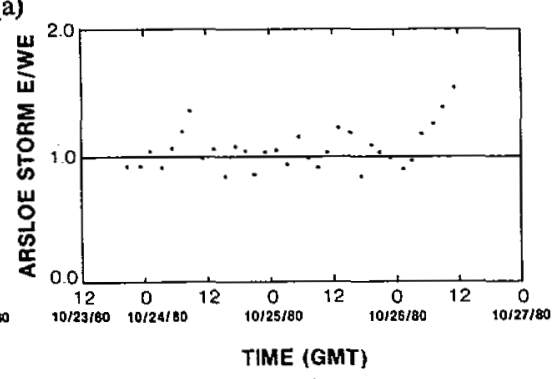

(c)

Fig. 2. Ratios of simultaneous $H_{s}$ values from buoy pairs: (a) ARSLOE ALPHA for the two outermost Waveriders (WN/WS) during ARSLOE ALPHA; (b) for Waveriders North and South (WN/WS), and (c) for the ENDECO and Waverider East (E/WE), during the ARSLOE storm.

TABLE II

RESULTS OF TESTS BETWEEN SIGNIFICANT WAVEHEIGHTS $\left(H_{s}\right)$

\begin{tabular}{|c|c|c|c|}
\hline Buoy Pair & $\begin{array}{c}\text { Number of } \\
\text { Compar isons }\end{array}$ & $\begin{array}{r}\text { Percent Faj lure of } \\
\text { F-Test at } 90 \% \text { Leve } \\
\end{array}$ & $\begin{array}{l}\text { Bias (Mean Ratio } \\
\text { of Occurrence of } \\
\text { the Higher } H_{s} \text { ) }\end{array}$ \\
\hline $\begin{array}{l}\text { ARSLOE } \\
\text { ALPHA } \\
\text { HN/HS }\end{array}$ & 57 & 9 & $1: 0.97$ \\
\hline $\begin{array}{l}\text { ARSLOE } \\
\text { STORM } \\
\text { HN/WS }\end{array}$ & 32 & 47 & $1: 0.39$ \\
\hline $\begin{array}{l}\text { ARSLOE } \\
\text { STORM } \\
\text { E/HE }\end{array}$ & 32 & 44 & $1: 0.62$ \\
\hline
\end{tabular}

\section{RESULTS}

Fig. 3 displays the time history of the suite of wave parameters: significant waveheight, frequency of the spectral peak, and mean wave direction of the spectral peak. When interpreting these plots, the locations of the different measurement systems must be taken into account. In Fig. 3, the notation " 1 " located above the symbol for the Cloverleaf data represents those data recorded within $1 \mathrm{~km}$ of the $12-\mathrm{km}$ site. The " 2 " above the symbol represents those data recorded within $3 \mathrm{~km}$ of the $36-\mathrm{km}$ site. All other Cloverleaf data shown were taken between these locations.

\section{A. Significant Waveheight}

Significant waveheights from several measurement systems are plotted in Fig. 3. Of the in situ systems clustered at the center of the $12-\mathrm{km}$ site, only the Waverider East (WE) and the ENDECO (E) (Fig. 1) collected a suitably long set (32) of simultaneous observations during the storm for a meaning. ful comparison. Separation between these two buoys was approximately $150 \mathrm{~m}$.

Table II summarizes results of different tests performed
TABLE III

COMPARISON OF SIGNIFICANT WAVEHEIGHTS MEASURED BY THE WAVERIDER LAST BUOY WITH OTHER SYSTEMS AT THE $12-\mathrm{km}$ SITE

\begin{tabular}{|c|c|c|c|}
\hline $\begin{array}{l}\text { Measurement } \\
\text { System } \\
\end{array}$ & $\begin{array}{c}\text { Nunber of } \\
\text { Comparisons }\end{array}$ & $\begin{array}{l}\text { Mumber Withir Waverider } \\
902 \text { Confidence Limits }\end{array}$ & $\begin{array}{l}\text { Percentage lit thin Haverider } \\
909 \text { Confidence Lipits }\end{array}$ \\
\hline EHDEC $0^{*}$ & 20 & 13 & 65 \\
\hline ENDECO\#* & 12 & 4 & 33 \\
\hline ENDECO $\approx \star \star$ & 32 & 17 & 53 \\
\hline Cloverleaf & 8 & 1 & 12 \\
\hline Met & 2 & 2 & -- \\
\hline
\end{tabular}

* OnIy those measurements taken before frontal passage on October 25, 1980 ** Only those measurements taken after frontal passage on 0ctober 25,1980
$\star * *$ For all measurements

on pairs of simultaneous $H_{s}$ values. The table includes results of the tests using the ARSLOE ALPHA data already discussed in the Introduction. Also included in Table II are results of comparisons involving the Waveriders $15 \mathrm{~km}$ North (WN) and South (WS) of the Waverider East buoy. These Waveriders were the same ones previously located 1 $\mathrm{km}$ apart during the ARSLOE ALPHA. Observations were available from these Waveriders for the same times as for the E/WE pair. Fig. 2(b) and Table II show that $H_{s}$ values from the Waverider North buoy during the storm period have a tendency to be higher than those from the Waverider South buoy. This bias is interpreted as being due to differences in the actual $H_{s}$ at the two locations since the same two instruments showed no bias during the ARSLOE ALPHA experiment.

Fig. 2(c) shows the ENDECO buoy tends to give $H_{s}$ values higher than the Waverider East buoy. It would be expected that these two buoys, being only $150 \mathrm{~m}$ apart would be sampling the same population; thus this bias is attributed to differences in the total buoy sytems. As seen in Table 

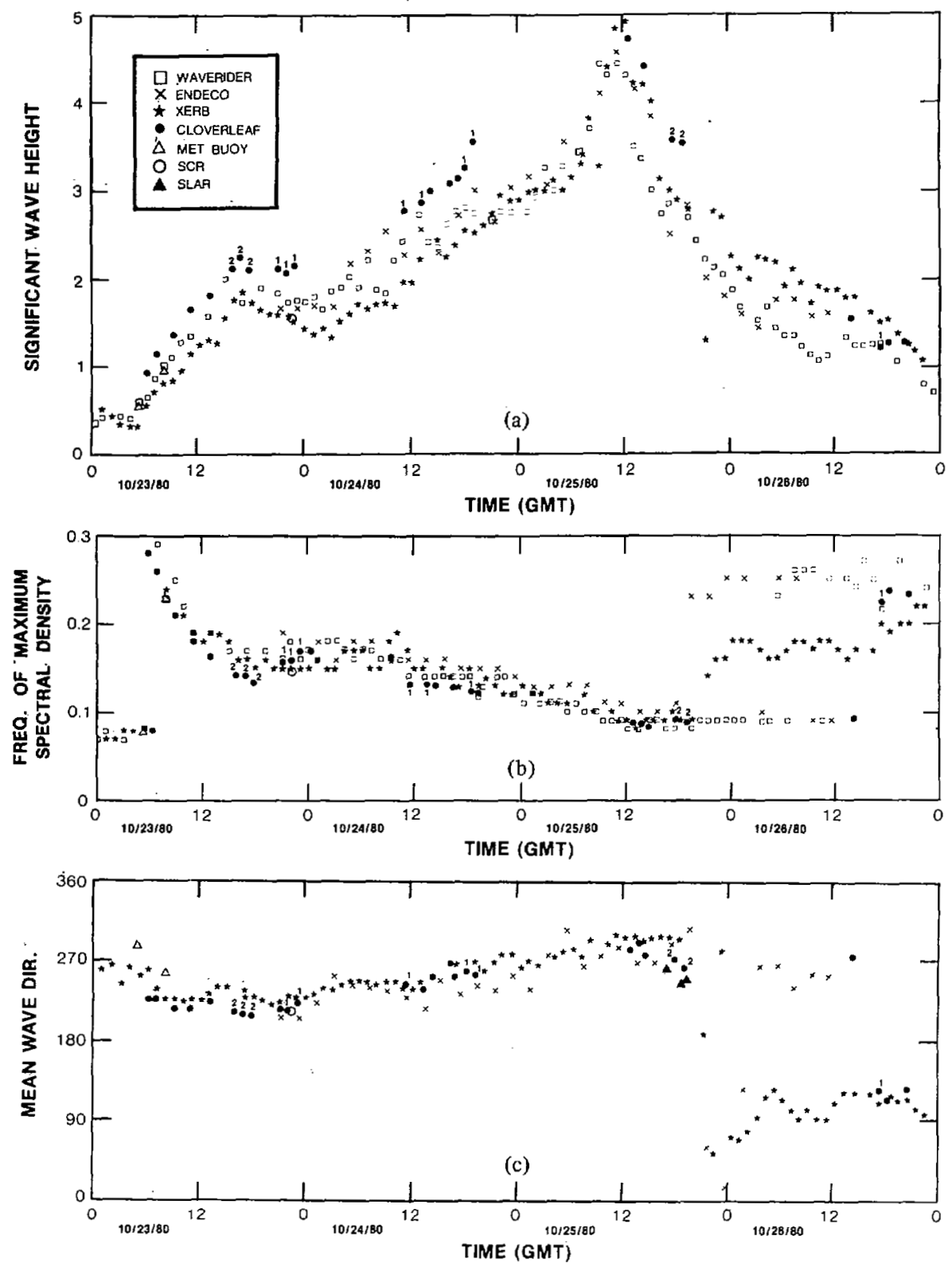

Fig. 3. Wave parameters: (a) Significant waveheight, (b) Frequency of maximum spectral density, (c) Mean wave direction for the frequency of maximum density.

II, the E/WE pair showed failure of the $F$ test at a level comparable to that of the WN/WS pair. According to the Binomial Distribution, the probability of that level of failure for the $\mathrm{E} / \mathrm{WE}$ pair being a ehance occurence is 0.0000008 . Thus it is concluded that the Waverider and ENDECO buoys yield different results for significant wàveheight.

As shown in Fig. 3(a) and summarized in Table III, the significant waveheights measured by the Waverider East and ENDECO buoys had better agreement before passage of the front, midday (GMT) on October 25. Then ENDECO and Waverider East agreed within the Waverider 90-percent confidence limits, 65 percent of the time. After the passage of the front, the agreement decreased to 33 percent.

It was not possible to identify the causes(s) of the discrepancies in significant waveheights between the ENDECO and Waverider East from comparison of the nondirectional spectra. However, the comparison did reveal some basic discrepancies between the spectra. The examples in Fig. 4 represent spectra normalized by their respective total spectral density. For this comparison, the spectral estimates for the Waverider were averaged by a moving window over 50 frequency bands to approximate the resolution of the available spectra from the ENDECO. It was found that spectral peaks from the ENDECO data were generally broader at the lower frequencies than those from the Waverider data. A possible cause for this could be the different type of window applied. It was also found that the high-frequency end of the Waverider spectra did not trail off as quickly as for the ENDECO spectra. The dotted curves in Fig. 5 are the Kitaigorodskii et al. theoretical curve for the equilibrium range computed using a representative water depth at the $12-\mathrm{km}$ site and normalized relative to the total spectral density in the corre- 


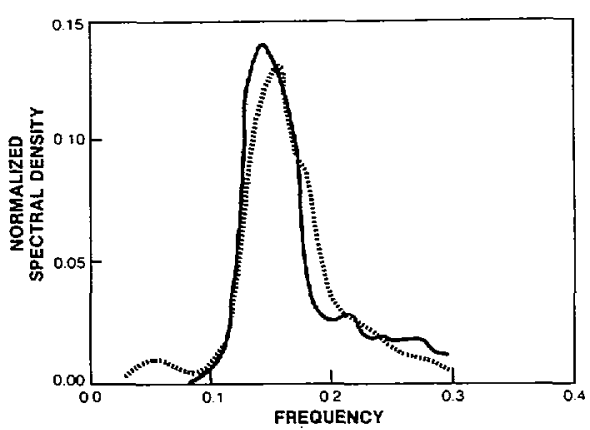

(a)

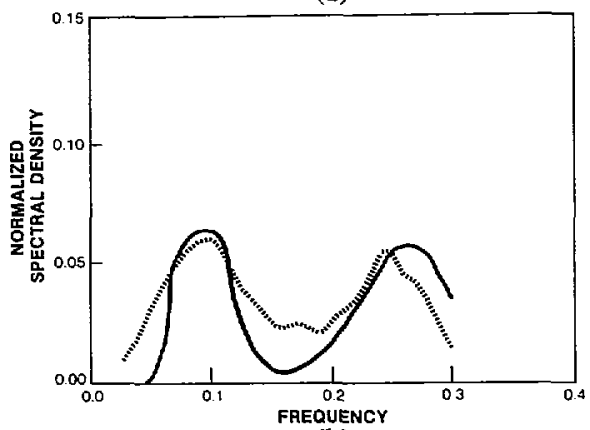

(b)

Fig. 4. Spectral density for Waverider East (- - ) and ENDECO (---); (a) $24 \mathrm{~h}$ before the frontal passage midday October 25,1980 , (b) $21 \mathrm{~h}$ after frontal passage.

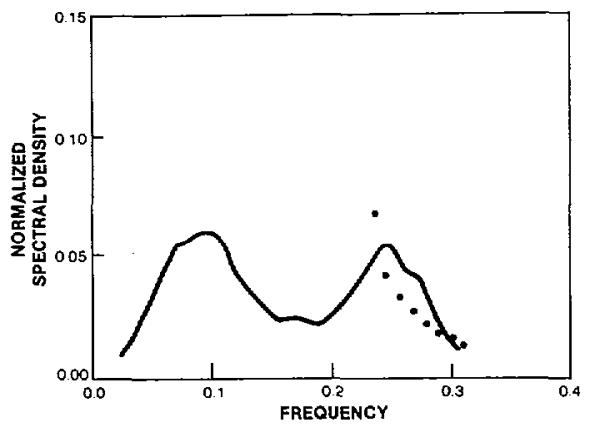

(a)

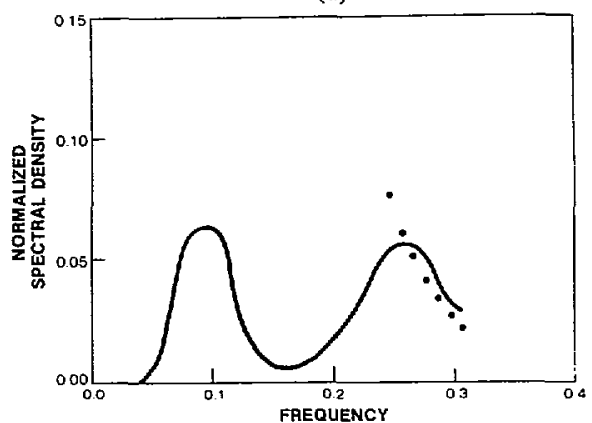

(b)

Fig. 5. Comparison of normalized spectra in Fig. 4 with identically normalized limiting depth related equilibrium spectrum according to Kitaigorodskii et al.; (a) for ENDECO; (b) for Waverider East.

sponding spectrum. It can be seen that the Waverider East data fit the theoretical curve better than the ENDECO [5]. A possible reason for this may be the differences in buoy response.

The comparison between the Canadian "MET" buoy and the Waverider East is limited to two measurement periods early on October 23. Although these data are insufficient to draw conclusions, Table III shows that the significant waveheights measured by the "MET" buoy were within the 90-percent confidence limits of the Waverider.
The significant waveheights measured by the Cloverleaf buoy were found to be consistently higher than those measured by nearby systems. When compared with the values measured at the $12-\mathrm{km}$ site by the Waverider East buoy, the Cloverleaf data averaged 15 percent higher. There was one measurement at 17:15 GMT on October 26, when the Cloverleaf measurement was within the Waverider 90-percent confidence limits. The Cloverleaf buoy measurements taken near the $36-\mathrm{km}$ site averaged 20 percent higher than those taken by the XERB buoy.

The Surface Contouring Radar (SCR) was flown over the experiment area at 22:20 GMT on October 23. The Waverider which was deployed $20-\mathrm{km}$ offshore at the center of the SCR pattern malfunctioned and thereby limited the ground truth data to those data measured at the 12 - and $36-\mathrm{km}$ sites. The significant waveheight of $1.55 \mathrm{~m}$ measured by SCR had better agreement with that measured by XERB $(1.58 \mathrm{~m})$ at $36 \mathrm{~km}$ offshore than with the Waverider East $(1.73 \mathrm{~m})$ at $12 \mathrm{~km}$ offshore. This might be expected since the bottom slope was greater between the $12-$ and $20-\mathrm{km}$ site than between the 20 - and $36-\mathrm{km}$ site.

\section{B. Frequency of Spectral Peak}

The central frequencies of the bands with maximum spectral density for the different measurements systems are plotted in Fig. 3(b). After the fronts passed through the site on October 25 , nearly opposing waves developed. The spectral densities associated with the existing old sea (swell) and with the newly developed sea were at times approximately equal. This led to the bifurcation shown in Fig. 3(b). Table III summarizes comparison of the frequencies of maximum density for single-peak spectra. As shown in Fig. 3(b), the Waverider East measured the spectral maximum at a lower frequency than the ENDECO. Although this difference is a consistent shift in the spectra, 83 percent of the time it was within the ENDECO frequency resolution of $\pm 0.025 \mathrm{~Hz}$.

Of the two pairs of spectra from the "Met" and Waverider East buoys available for comparison, one was unimodal and the other bimodal. The central frequencies of the spectral maxima agreed for both cases.

The frequencies of the spectral maxima for the Cloverleaf spectra were generally in agreement with those of spectra from nearby buoys. When compared with the Waverider East during both swell and sea, the distribution indicated no bias, and agreement between these frequencies within their frequency resolution occured 71 percent of the time. When compared with XERB, agreement was found 80 percent of the time. The frequency of the spectral maxima for the XERB spectra were biased higher than the Cloverleaf spectra by an average of $0.014 \mathrm{~Hz}$.

When comparing the frequencies of waves resulting from buoy measurements to those obtained from a remote sensor such as the SCR, it is important to keep in mind that remote sensors measure in wavenumber space and then the frequency is computed using linear wave theory. Despite this, the frequencies of maximum spectral density obtained from the October 23 SCR flight were similar to those from the buoys in the area. From the SCR measurements, the frequency of the spectral peak at 22:20 GMT was calculated to be 0.147 
TABLE IV

COMPARISON OF FREQUENCY OF MAXIMUM DENSITY FOR SINGLE-PEAK SPECTRA

\begin{tabular}{|c|c|c|c|c|}
\hline $\begin{array}{l}\text { Measurement System } \\
\text { Systeni A/System B }\end{array}$ & $\begin{array}{l}\text { Number of } \\
\text { Comparison }\end{array}$ & $\begin{array}{l}\text { Rumber bithin } \\
\text { Frequency } \\
\text { Resolution }\end{array}$ & $\begin{array}{l}\text { Percent } l_{1}^{i} t^{\text {rin }} \\
\text { Frequency } \\
\text { Resolutirl* }\end{array}$ & $\begin{array}{l}\text { Erequency } \\
\text { Resolution } \\
\text { (hertz) } \\
\text { Sys } A / \text { Sys E }\end{array}$ \\
\hline & & 1 & 83 & $.011 / .025$ \\
\hline WE & 2 & 2 & - & $.011 / .010$ \\
\hline WE/SCR & 1 & i & & $.011 / * *$ \\
\hline $\mathrm{HE} / \mathrm{Cl}$ nverleaf & 7 & 5 & 71 & $.011 / .007$ \\
\hline $\mathrm{XERB} /$ Cloverlea $f$ & 5 & $c$ & ח & $.010 \% .007$ \\
\hline $\mathrm{XERB} / \mathrm{SC}$ & 1 & 1 & - & $.010 / * \star$ \\
\hline
\end{tabular}

- Resolution used was the larger value of System $A$ or $B$

* SCR resolution of data in wave number space

$\mathrm{Hz}$. During this period, the Waverider spectra indicated the spectral peak at $0.145 \mathrm{~Hz}$, the XERB at $0.149 \mathrm{~Hz}$.

\section{Mean Wave Direction of the Spectral Peak}

The mean wave directions for the frequency of the spectral peaks are summarized in Fig. 3(c) for those systems providing wave direction. Wave directions are referenced to True North and indicate the direction towards which waves propagate. The comparison of wave direction pertains only to mean wave direction. The mean wave direction $\bar{\phi}(f)$ for each frequency band was computed for the directional wave buoy systems from

$$
\bar{\phi}(f)=\tan ^{-1}\left[b_{1}(f) / a_{1}(f)\right]
$$

where $a_{1}$ and $b_{1}$ are the Fourier coefficients from the weighted Fourier expansion

$$
\begin{gathered}
F(f, \phi)=1 / 2 a_{0}+c_{1}\left[a_{1} \cos (\phi)+b_{1} \sin (\phi)\right] \\
+c_{2}\left[a_{2} \cos (2 \phi)+b_{2} \sin (2 \phi)\right]
\end{gathered}
$$

of Longuet-Higgins et al. [6].

Comparisons of mean wave directional results from in situ systems are made only when the systems were close. As shown in Table $\mathrm{V}$, mean wave directions from the Cloverleaf and ENDECO buoys agreed within 5 to $20^{\circ}$. The wave direction measured by the Cloverleaf buoy was slightly more northerly than indicated by the ENDECO buoy. Similar agreement was shown between the Cloverleaf and the XERB buoys. Difference in their mean wave direction ranged between 1 and $24^{\circ}$. The Cloverleaf buoy indicated a more southerly direction than the XERB.

Data from the SLAR overflight near the $12-\mathrm{km}$ site on October 25 did not coincide with the available ENDECO data. The nearest measurements were about an hour apart. The ENDECO buoy, as shown in Fig. 3(c), indicates a more northerly direction than the SLAR.

Surface Contouring Radar measurements taken in the region $20 \mathrm{~km}$ offshore on Octoher 23 agreed with those measured at the $12-\mathrm{km}$ site by the Cloverleaf buoy. The SCR measured the wave direction to be $210^{\circ}$, while the Cloverleaf measured the direction at $212^{\circ}$. At the same time, the XERB at $36 \mathrm{~km}$ offshore measured the wave direction at $226^{\circ}$.

When the Canadian "MET" buoy recorded measurements on October 23, there was no other wave-direction data available at the $12 \mathrm{~km}$ site. The only other system measuring wave direction at this time was XERB, some $24 \mathrm{~km}$ further off-
TABLE V

COMPARISON OF MEAN WAVE DIRECTIONS MEASURED BY

\begin{tabular}{|c|c|c|c|}
\hline Measurement System & $\begin{array}{c}\text { Humber of } \\
\text { Comparisons } \\
\end{array}$ & $\frac{\text { Differences }}{\text { Range }}$ & $\begin{array}{c}\text { in Degrees } \\
\text { Average }\end{array}$ \\
\hline $\begin{array}{l}\text { ENDECO } \\
\text { XERB }\end{array}$ & $\begin{array}{l}4 \\
5\end{array}$ & $\begin{array}{l}4-20 \\
1-24\end{array}$ & $\begin{array}{l}14 N \\
16 S\end{array}$ \\
\hline
\end{tabular}
THE CLOVERLEAF BUOY WITH OTHER DIRECTIONAL BUOYS

shore. The "MET" data during this time show the wave direction to be $30^{\circ}$ more northerly than that measured by XERB.

\section{ACKNOWLEDGMENT}

The following ARSLOE participants are thanked for making their data available for this preliminary comparison: H. Mitsuyasu (Cloverleaf buoy), Kyushu University; M. Skafel (MET buoy), National Water Research Institute, Canada Centre for Inland Waters; L. LeBlanc (ENDECO Wavetrack buoy), University of Rhode Island; E. Walsh (SCR) NASA Wallops Flight Center; D. Ross (SLAR), NOAA Atlantic and Meteorological Laboratories; and K. Steele (XERB), NOAA Data Buoy Office.

The authors express appreciation to Prof. W. J. Pierson for his useful comments and suggestions, L. Hart for his assistance in data processing and preparation, and L. Collins and C. Hurley for their assistance in preparing the manuscript.

\section{REFERENCES}

[1] L. D. Burroughs, "Analyses of elements of the marine environment for the atlantic remote sensing land ocean experiment (ARSLOE)," in 'Proc. Oceans'82 Conf. (Washington, DC), 1982.

[2] R. L. Ribe, "Calibrations and energy correction factors for waverider buoys deployed under the ARSLOE program," NOAA/ESO, Tech. Rep. TE 3-81-012, Nov, 1981.

[3] L. A. Kahn, "A shallow water intercomparison study of two wave measuring buoys," EG\&G Washington Analytical Services, Inc. Rep. TR-E930-0003, Mar. 1982.

[4] M. S. Longuet-Higgins, "On the statistical distribution of the heights of sea waves," J. Marine Res., vol. XI, no. 3, 1952.

[5] S. A. Kitaigorodskii, V. P. Krasitski, and M. M. Faslavskii, "On phillips' theory of equilibrium range and the spectra of wind-generated gravity waves," J. Phys. Ocean., vol. V, p. 410-420, 1975.

[6] M. S. Longuet-Higgins, D. E. Cartwright, and N. D. Smith, "Observations of the directional spectrum of sea waves using the motions of a floating buoy," in Proc. Int. Symp. Ocean Wave Spectra. Englewood Cliffs, NJ: Prentice-Hall, 1963.

Michael W. Szabados was born on January 15, 1950, in Levitton, NY. $\mathrm{He}$ received the B.Sc. degree in physics (Hons.) from the New York Institute of Technology in 1972 and the M.Sc. in physical oceanography from University of Connecticut in 1975.

He spent three years as an Oceanographer with the Envirosphere Company. He has spent the past six years with the National Oceanic and Atmospheric Administration. His research activities and interests encompass wind generated waves, tidal dynamics, and estuarine circulation.

Mr. Szbados is a member of the National Society of Physicists.

Dinorah C. Esteva holds a Doctor in Science degree from the University of Havana, Cuba, and a M.S. in physics from Rensselaer Polytechnic Institute, Troy, NY.

She spent eleven years at the U.S. Army Coastal Engineering Research Center, Fort Belvoir, VA, where she was involved in the study of wave characteristics in the coastal zone and in their simulation in hydraulic laboratory facilities. In 1979, she transferred to the National Oceanic and Atmospheric Administration, Coastal Waves Program.

Ms. Esteva is a member of the Sigma Pi Sigma Physics Honor Society and of the American Geophysical Union. 